\title{
El discurso paramilitar de alias '39': sospechosos, infractores y redimidos en La Mesa, Cesar **
}

\author{
The paramilitary speech Alias '39': suspects, offenders \\ and redeemed in La Mesa, Cesar \\ O discurso paramilitar do, mais conhecido como '39': \\ suspeitos, infratores e redimidos em La Mesa, Cesar
}

\footnotetext{
* Licenciado en Filosofía de la Universidad del Valle. Magister en Comunicación. Periodista profesional con 29 años de experiencia en Prensa (EL PAIS de Cali y EL TIEMPO) y Noticieros de Televisión (TV-HOY, CM\&, Canal RCN y Noticias UNO). Correo electrónico: magregor@hotmail.com.

${ }^{* *}$ Este trabajo constituye un apartado de la investigación realizada como trabajo de grado para la Maestría en Comunicación, realizada en la Pontificia Universidad javeriana de Bogotá. El trabajo de grado se titula: Lugaresy artefactos de la memoria: relatos de la violencia paramilitar en La Mesa, Cesar (1999-2006). Artículo de reflexión recibido el 30/06/2016 y aceptado el 19/07/2016.
} 

El trabajo caracteriza el discurso paramilitar en el corregimiento de La Mesa, Cesar, cuyas prácticas de poder-saber no están inscritas únicamente en el campo coercitivo, sino que se extienden a formas de comunicación. Estas formas son escenarios donde el control y el sometimiento de la población, la legitimación y deslegitimación del enemigo principal (FARC, ELN y sospechosos) y el habitante problemático (los infractores), adquieren una forma particular de inscripción en las individualidades y el cuerpo social, y se extiende, como correlato, a la cancha de fútbol, la escuela, las calles, los lugares de trabajo, los artefactos (piedra y arcos de fútbol) presentes en el territorio. Además de sospechosos e infractores, el jefe paramilitar, David Hernández Rojas, alias '39', dio origen a otro sujeto inscrito en su discurso: los redimidos/colaboradores.

PALABRAS CLAVE:

Discurso | orden del discurso | artefacto | régimen poder-saber

The paper aims to characterize the paramilitary speech in the village of La Mesa, Cesar, whose practices of power-knowledge are not registered only in the coercive field, but extend to forms of communication, where control and subjugation of the population, legitimation and delegitimation of the enemy and unwanted (FARC and ELN, suspects and offenders) acquire a particular form of registration in the individualities and the social body, and extends, as a correlative to the soccer field, school, the streets, workplaces, artifacts (stone and arches soccer) in the territory. In addition to suspects and offenders he led to another subject registered in the speech, the redeemed. The relationship of what to do and not doing, unfurled a control technique to establish a regime of violence-discipline, linked to a prohibitive know, discriminant, who submitted the minds, bodies, actions and decisions of the people in their inter-relations and community practices.

\section{KEYWORDS:}

Speech | speech order | devic | system power-knowledge 
O trabalho visa caracterizar o discurso paramilitar no corregimento de La Mesa, Cesar, cujas práticas de poder-saber não estão inscritas somente no campo coercitivo, mas também que estendem--se a formas de comunicação, cenários onde o controle e a submissão da população, a legitimação e deslegitimação do inimigo principal (FARC, ELN e suspeitos) e o habitante problemático (os infratores), adquirem uma forma especial de inscrição nas individualidades e no corpo social, e amplia-se, como correlato, ao campo de futebol, a escola, as ruas, os lugares de trabalho, os artefatos (pedra e arcos de futebol) presentes no território. Além de suspeitos e infratores, o chefe paramilitar, David Hernández Rojas, vulgo '39', originou outro sujeito inscrito em seu discurso: os redimidos/colaboradores.

\section{PALAVRAS CHAVES:}

Discurso | ordem do discurso | artefato | regime poder-saber 


\section{La llegada de la violencia no invitada a La Mesa, Cesar ${ }^{1}$}

La vida de las familias campesinas del corregimiento de La Mesa, norte de Valledupar, empezó a transformarse el sábado 23 de septiembre de 1999 a las cinco de la madrugada, con la llegada de un grupo de hombres armados, vestidos con uniforme camuflado y los rostros cubiertos con pasamontañas. Estos, luciendo sus fusiles Galil y R-15, recorrieron las calles del caserío.

El arribo de hombres armados sorprendió a algunos de los pobladores que se dirigían a esa hora a las fincas de la zona para 'jornalear'. Los hombres armados no pronunciaron palabra y se dirigieron a las trochas que llevan hasta las veredas El Mamón y Azúcar Buena. Nadie sabía qué grupo armado había arribado al pueblo, a pesar de que a lo largo de diez años se habían acostumbrado a la presencia de grupos armados en la región.

La guerrilla empezó a hacer presencia en la zona rural del norte del Cesar a principios de la década del ochenta. Para las Farc (Bloque Caribe) y el ELN (Frente 6 de diciembre) significó una zona de descanso por su ubicación geográfica y su cercanía a la Sierra Nevada. Esto les permitió, en muchos casos, replegarse rápidamente y contraatacar al Ejército, que los perseguía con unidades de contraguerrillas del Batallón La Popa de la Décima Brigada.

Por su riqueza agrícola ${ }^{21}$ y posición estratégica, la zona norte de Valledupar le permitía a la guerrilla - asentada en veredas y corregimientos- la explotación de recursos para su financiamiento, provenientes del secuestro y la extorsión entre agricultores, ganaderos, comerciantes y la población urbana.

Ante la inoperancia de las autoridades de Policía y el Ejército, que no evitaban los atentados contra sedes de las alcaldías locales, estaciones, los asesinatos selectivos y la

\footnotetext{
1. Para la construcción de este documento, desde el análisis crítico del discurso y haciendo uso del método etnográfico, se hizo un trabajo de campo intensivo de inmersión entre las comunidades del corregimiento de La Mesa, Cesar, y sus veredas. Se llevaron a cabo más de treinta entrevistas en profundidad y se construyeron cinco crónicas testimoniales a víctimas y testigos de la violencia ejercida por los paramilitares del Bloque Norte. Se analizan los cambios y modificaciones sufridos en los imaginarios y sentidos de los habitantes, cambios y modificaciones vinculados con los lugares y los artefactos, y la deconstrucción-reconstrucción de estos sentidos por los victimarios.

2. Como la mayoría de los departamentos de la costa Atlántica, la estructura agraria del Cesar está dominada por las grandes haciendas de ganadería extensiva, con pequeñas áreas de agricultura comercial y una población campesina minifundista dedicada a los cultivos de subsistencia y a la pequeña ganadería, que ocupan tierras marginales alrededor de los pueblos y caminos secundarios. La configuración geográfica permite al Cesar caracterizarse por una gran variedad de climas y una diversidad de formaciones geográficas (montañas, riberas, llanuras), atravesadas por los ríos Cesar y Ariguaní en el norte y en el centro del departamento, donde se extienden llanuras que contrastan con la franja oriental en la que se ubica la serranía del Perijá y la Sierra Nevada en el noroccidente. El centro, cercano al río Magdalena, presenta suelos inundables, y el sur, como franja territorial de conexión entre la zona Andina y Caribe, basa su economía en el modelo agroindustrial con la palma de aceite o palma africana.
} 
poca atención del gobierno central a la situación de orden público, algunos dirigentes políticos y ganaderos utilizaron ejércitos privados para defenderse de la extorsión guerrillera.

En 1995, estos decidieron acudir a los jefes paramilitares, Carlos Castaño y Salvatore Mancuso, fundadores de las Autodefensas Unidas de Colombia, AUC, para que apoyaran la estrategia de defensa privada frente al poder depredador de las Farc y el ELN, resguardar sus haciendas y fincas, y poder contrarrestar las extorsiones y secuestros. El propósito encubría la expulsión de miles de familias campesinas beneficiadas con la titulación de tierras en las décadas del sesenta y setenta, acusándolas de apoyar a la guerrilla y de tomarse políticamente la administración local y regional, a través de las alcaldías y la gobernación.

Un representante de la vieja élite vallenata, Rodrigo Tovar Pupo, decidió crear el Bloque Norte de los paramilitares, desatando una oleada de asesinatos selectivos, masacres, desplazamiento de campesinos, despojo de fincas y tierras de más de 7000 familias en zona rural de Pueblo Bello, El Copey, Codazzi, Valledupar, Becerril, La Jagua de Ibirico, San Diego, Pailitas, Curumaní, San Alberto, Bosconia y Astrea, entre 1998 y 2005.

Hacia mediados del 2000, el paramilitarismo en el Cesar se desplegó rápidamente, copando los espacios políticos, económicos y sociales del departamento.

\section{Llegó '39'}

El corregimiento de La Mesa está ubicado a treinta minutos, por carretera, de Valledupar, la capital del Cesar, y a diez kilómetros del cuartel general del batallón La Popa del Ejército. Ese año, el caserío estaba habitado por 1200 habitantes, algunos de los cuales eran propietarios de fincas, otros trabajaban como jornaleros en las parcelas y otros se dedicaban a la ganadería. La economía familiar dependía - como hoy en día- del autoabastecimiento proporcionado por la yuca, el plátano, el maíz, el frijol y los frutales, así como el cuidado de aves y porcinos. Todo esto llevó a La Mesa a ser reconocida como la "despensa de Valledupar".

A las nueve de la mañana del 23 de septiembre, varios hombres armados llegaron hasta la casa del corregidor, Manuel Francisco Molina Álvarez. Su esposa, quien abrió la puerta, se llevó tremendo susto al ver que hombres encapuchados preguntaban por él para informarle que avisara a los habitantes sobre una reunión a las tres de la tarde en la cancha de fútbol, ubicada a la entrada del pueblo. Molina Álvarez no estaba en casa, había salido a realizar una diligencia a Valledupar, por lo que su mujer se comunicó con él por teléfono celular para avisarle de la reunión. De inmediato, el corregidor se comunicó con los líderes de las nueve veredas para avisarles que debía verlos a las tres de la tarde en la cancha de fútbol. Un mal presentimiento invadió su estado de ánimo. 
A las dos de la tarde, la gente empezó a llegar en medio de un sofocante calor de 38 grados a la sombra. En el sitio, unos cuarenta hombres armados vigilaban la llegada de los pobladores, mientras las mujeres portaban en sus manos paraguas de colores para librarse de los rayos del sofocante sol. Cuarenta y cinco minutos después llegaron cuatro camionetas con vidrios polarizados y se parquearon a un lado de uno de los arcos de la cancha de fútbol. De una de ellas se bajó el que parecía ser el comandante, escoltado por diez hombres fuertemente armados. El hombre, con sombrero de pava y el rostro cubierto por una pañoleta negra, subió a una pequeña tarima ubicada frente a los nueve líderes veredales, el corregidor y los habitantes que lo esperaban.

El jefe del grupo armado se mostró desafiante. A su lado estaba John Jairo Hernández Sánchez, alias Centella, su conductor, y John Jairo Esquivel Cuadrado, alias el Tigre, quien parecía ser su segundo al mando. Luego, tomó la palabra y se dirigió a los pobladores para decirles: "Las autodefensas llegamos a La Mesa para limpiarla de guerrilla (Farc y ELN). El que quiera seguirnos no va a tener problemas, pero el que no se alineé debe atenerse a las consecuencias". 3

En seguida se bajó de la tarima, caminó y se dirigió hasta donde estaban los líderes comunitarios y los increpó: "Yo soy de aquí, soy de la región. Los conozco a todos ustedes y sé quién está con quién. Ahora las cosas van a ser de otro modo, venimos a quedarnos por tiempo indefinido".

Al otro día, domingo 24 de septiembre, el jefe paramilitar ordenó de nuevo una reunión con los habitantes en un salón del colegio de bachillerato Virgen del Carmen. De espaldas al tablero y en tono desafiante ordenó entregarles la cartilla de educación cívica, con el horario que regiría para las actividades que se llevarían de ahí en adelante en el pueblo: "La deben leer todos. Allí está lo que deben hacer para que no tengan problemas con nosotros. Todos los días deben salir a las siete de la mañana a las fincas y parcelas a trabajar y regresar al pueblo a las tres de la tarde, para que cumplan con trabajos comunitarios, de limpieza, arreglar los frentes de la casa que están dañados, desyerbar andenes, limpiar caminos. No quiero vagos aquí, el que roba es porque está desempleado, entonces vamos a trabajar todos".

A partir de ese día quedó prohibido circular por las calles después de las seis de la tarde hasta las seis de la mañana y a las ocho de la noche las luces de las viviendas debían estar apagadas.El jefe les dijo que lo podían llamar comandante '39' y reiteró que “Quien tenga vínculos con las Farc y el ELN debe confesarlo para no tener problemas y si no lo hacen, nosotros lo averiguaremos y sus familias sufrirían las consecuencias. Tengo una lista del tamaño de una hoja de periódico con nombres de sapos de la guerrilla. Así que deben hablar". ${ }^{4}$ Luego ordenó que las mujeres arreglaran el pueblo, "barriendo y

\footnotetext{
3. Testimonio de Manuel Francisco Molina Álvarez, fundador y primer corregidor de La Mesa.

4. Testimonio de Miguel Lascarro Molina, corregidor de la Mesa.
} 
limpiando las calles", y a los hombres que organizaran el frente de las casas, "pintando las puertas con los colores de la bandera de Colombia, lo mismo que los postes de alumbrado público, árboles y piedras".

Pronto los habitantes de La Mesa se enteraron quién era el comandante del frente paramilitar que ocultaba su identidad detrás de la pañoleta negra. Era David Hernández Rojas, un mayor del Ejército, prófugo de la Justicia, que sirvió en el batallón La Popa de Valledupar como comandante del Batallón de Granaderos, combatiendo a las milicias de las Farc. Hernández había crecido en las calles y campos de La Mesa, cuando guerrilleros del ELN se paseaban por las veredas de la zona.

Varios de los habitantes de La Mesa recuerdan que, a finales de la década del setenta, su padre compró una finca en la vereda La Sierra donde crecieron David y sus dos hermanos, Orlando y Levi, quienes iban a estudiar a la escuela La Montaña con los hijos de otras familias campesinas de la zona.

"Yo lo reconocí desde el primer momento -dijo el corregidor-, aunque tenía cubierto su rostro. Su voz me era familiar y me acordé de él: era Davisito, el segundo hijo de los Hernández, que estudió en La Montaña con mi hijo mayor. Ellos crecieron viendo a los 'elenos' llegar a la finca de los Hernández Rojas y exigir el pago de la vacuna, en dinero o en ganado".

La Mesa fue el punto de avanzada del control del norte del Cesar por parte de alias Jorge 40, quien ordenó a '39' tomarse a sangre y fuego esa región para arrebatársela al ELN y frenar las pretensiones de las Farc, y así mantener la presencia del Bloque Caribe, que comandaba Ricardo Palmera, alias Simón Trinidad, un viejo amigo de Jorge 40.

En la reunión en el colegio '39' dividió a los habitantes en dos grupos: los sospechosos y los infractores. "Los sospechosos son los que tienen vínculos con la guerrilla, los que le trabajan como informantes, guías y les venden alimentos. Los infractores son los borrachos, los ladrones, los infieles -sean hombres o mujeres-, los drogadictos, los mujeriegos. Para todos hay castigo si no se alinean y cumplen con las disposiciones que están en la cartilla de educación y comportamiento que deben leer todos".

Luego, caminando por entre los pupitres ocupados por los pobladores advirtió: "Cuídense, yo los conozco a todos, sé quién es quién, no se busquen problemas, arreglen sus cuentas con nosotros, porque de aquí no nos vamos a ir hasta que esto no esté limpio completamente".

Una semana después, el jefe del frente Mártires del Valle de Upar instaló su centro de operaciones en la finca El Mamón, cedida por un ganadero de Valledupar, a cuarenta minutos de La Mesa. Hasta allí hacía subir a agricultores, comerciantes, tenderos, campesinos y transportadores para exigirles una cuota económica para que financiaran "la causa" y sostener la maquinaria de guerra que se instaló por siete años en el corregimiento. En El Mamón, en la mesa del comedor, ‘39' extendió un mapa del corregimiento 
y las veredas aledañas, sectorizó la zona y ordenó instalar tres retenes a lo largo de la vía a Valledupar, ubicar campamentos de vigías y habilitar campos de entrenamiento en algunas fincas despojadas a sus dueños.

De esta manera vigilaba las entradas y salidas del corregimiento y los caminos que conectan a las veredas El Mamón, Sabanita, Cuba y Las Estrellas, para tener controlados los movimientos de sus habitantes. En la entrada del pueblo, los paramilitares instalaron un retén frente a una piedra grande y allí hacían bajar a todos los ocupantes de los vehículos que salían o entraban a La Mesa, les pedían la cédula y comparaban sus nombres con una lista de sospechosos. Luego los separaban del grupo y ordenaban a los conductores continuar la marcha.

A los que figuraban en la lista los ubicaban en la piedra y los interrogaban, ordenándoles confesar sus nexos con la guerrilla y decir si en el pueblo había colaboradores. El 18 de diciembre de 1999, llegó al pueblo Salvatore Mancuso, comandante de las AUC, y visitó la piedra a la que llamó "la piedra de los milagros", porque aquellos que allí sentaban "confesaban la verdad".

Después, los sospechosos eran amarrados y subidos a una camioneta de color verde que los habitantes denominaron "La última lágrima" porque no volvían a verlos con vida. A otros se los llevaban a la montaña y los asesinaban.

El ritual se cumplía a distintas horas del día a la vista de sus familiares, vecinos y amigos, quienes no podían hacer nada, no importaba si había mujeres, niños, ancianos, era el ritual del terror. Los sobrevivientes a los interrogatorios llamaron a la piedra, "La piedra de los lamentos".

Los infractores, en cambio, eran conducidos hasta la cancha de fútbol para ser amarrados a los arcos y dejados semidesnudos a la intemperie. Las víctimas estaban expuestas a toda clase de inclemencias y necesidades, a las burlas de los victimarios, a la vergüenza de sus amigos y vecinos, al sufrimiento de sus familiares.Era el castigo por "violar las normas contempladas en el manual de educación cívica".

El asesinato de pobladores 'sospechosos' de ser guerrilleros o aliados del ELN empezó el 11 de diciembre de 1999 a las cinco de la madrugada. Ese día, quince paramilitares al mando de John Jair Esquivel Cuadrado, alias el Tigre, sacaron a seis personas de sus viviendas, señaladas de ser colaboradoras de la guerrilla, por una mujer encapuchada.

En medio de maltratos e improperios, las amarraron y las pasearon por las calles hasta conducirlas a la entrada del corregimiento. El Tigre6 acusó a las víctimas de ser

6. El 16 de agosto de 2011, el Juzgado Penal del Circuito de Descongestión Adjunto de Valledupar, condenó a veinticinco años de prisión a John Jairo Esquivel Cuadrado, alias el Tigre, como coautor de la masacre cometida el 11 de diciembre de 1999 en el corregimiento de La Mesa, donde murieron seis personas: Nelson Rafael Acosta Castro, Cesar Elías Ropain Jiménez, Nelson Rafael Acosta Carvajal, Alexander Mora Quesada, Roque Manuel Rubio y José María Arias Martínez. Según el expediente, la incursión armada fue guiada por María Flórez Castrillón, alias la Mona, exguerrillera del Frente 6 de diciembre del ELN, quien, lista en mano, señaló a las víctimas de ser colaboradoras de ese grupo guerrillero. 
'sapos',los obligó a acostarse boca abajo para ser ajusticiados. Luego ordenó dispararles en la cabeza y arrojar los cadáveres muy cerca a la cancha de fútbol, en medio de los gritos angustiados de sus familiares.

Los cuerpos baleados permanecieron cuatro horas en medio de charcos de sangre, sin que sus familiares pudieran hacer nada. Un vecino de una de las víctimas llegó al sitio con un camión y se ofreció a trasladar los cadáveres hasta Valledupar. Envueltos en sábanas, fueron ubicados en la parte trasera del vehículo, en medio de gritos de protesta por la masacre. Hacia el mediodía, unas doscientas personas, con maletas, enseres y animales, decidieron abandonar sus casas y fincas para desplazarse a pie o a caballo hacia Valledupar, protagonizando el primer desplazamiento campesino de La Mesa hacia la capital del Cesar, lo que provocó reacciones entre las autoridades locales y el gobernador Lucas Gnecco Cerchar. ${ }^{7}$

Del número de víctimas de la violencia paramilitar de La Mesa no se tienen estadísticas exactas, en el censo de la Unidad de Víctimas del gobierno nacional. El Bloque Norte de Jorge 40 dejó 1573 víctimas en 333 masacres, cometidas entre 1999 y 2005, en los departamentos de La Guajira, Cesar, Magdalena, Atlántico, Bolívar, Sucre y Córdoba. En La Mesa, los paramilitares de alias ‘39' y el Tigre cometieron tres masacres. Se calcula que las incursiones de los paramilitares dejaron dieciséis personas asesinadas en las nueve veredas vecinas y 540 más desplazadas.

\section{Introducción}

El trabajo tiene como propósito hacer una lectura de los conceptos integrados al análisis de Michel Foucault (1980) sobre la red de relaciones (dispositivo) poder-saber en la que se inscriben los discursos y las prácticas sociales, ${ }^{8}$ como momentos que se determinan mutuamente, la relación entre los distintos componentes como enunciados, medidas, decisiones, prácticas que circulan al interior de dichas relaciones.

\footnotetext{
7. El clan familiar Gnecco, oriundo de Sicilia, Italia, se asentó en el departamento de La Guajira, de filiación liberal, amasó fortuna durante el auge del contrabando y la bonanza marimbera en la década de los años setenta en la costa Atlántica. El negocio del clan familiar era el contrabando de café y vehículos provenientes de Venezuela. Controlado el aspecto económico de la región, por alianzas filiales con otras dos familias de la élite vallenata, el paso siguiente fue controlar el poder político. Algunos de sus integrantes se enriquecieron con esos dineros y pasaron a incursionar como clase emergente en el campo de la dirigencia política, además de la social y económica. Lucas Gnecco Cerchar representó a los nuevos actores políticos en el Cesar, que sin mayor tradición electoral, estuvo fundamentalmente respaldado por su poder económico ilegal. Eso les facilitó a los Gnecco usar prácticas como la compra de votos, lo que les permitió llegar a las posiciones de mando regional, como la gobernación, la alcaldía de Valledupar y el Senado de la República.

8. Fairclough asegura que en las prácticas sociales es posible identificar tipos de acciones, tipos de interacciones y las relaciones interpersonales. También diferentes formas de lenguaje verbal y no verbal, lo mismo que mecanismos simbólicos para interactuar.
} 
En tanto hace parte de la red de relaciones saber-poder, el discurso existe situado en un lugar y en un tiempo (Fairclough, 200o), y su emergencia (manifestación) responde siempre a un acontecimiento que lo hace aparecer, de modo que para hacerlo inteligible resulta necesario establecer sus condiciones de emergencia en tanto acontecimiento, que modifica un campo previo de relaciones de saber/poder/prácticas sociales.

También explora el concepto de práctica social en el que se integran sus formas de significar (lo semiótico) en las luchas por el ejercicio del poder, a la luz del análisis de la propuesta de trabajo de grado, la cual explora la representación simbólica y comunicacional dinamizadas por el discurso paramilitar sobre los lugares y artefactos.

Trataremos de ubicar las herramientas conceptuales de diagnóstico de Fairclough \& Wodak, (2000) y Jäger (2003), en el marco del Análisis Crítico del Discurso, ACD, para acercarnos a una lectura de lo que ocurrió en la población de La Mesa, sometida a un poder armado omnipresente, vigilante y controlador, que desencadenó, en una primera fase, un discurso de exclusión-inclusión, que actuó como técnica destinada a legitimary garantizar un orden (Jäger, 2003), incluyendo las estrategias de lo que podía o no decirse. Exclusiones e inclusiones que se consolidaron a través de prácticas instauradas en el tejido social de La Mesa, desencadenando procesos de desintegración individual y colectivas por una maquinaria de poder jerarquizado y especializado en castigar y asesinar.

Para Jäger (2003), el discurso - como realidad material con plena validez- produce realidad al ser transmitido por personas activas a una comunidad de hablantes, adquiriendo capacidad para inducir comportamientos y generar otros discursos. Es decir, adquiere una manifestación plena, aplicada a una realidad, estructurando relaciones de poder en la sociedad. Foucault (2006) ve una coexistencia entre discurso y realidad, el discurso es un escenario de luchas de poderes y sometimientos, en el que se despliegan procedimientos que tienen como función nombrar y anticipar acontecimientos en su materialidad, con el fin de agenciar exclusiones, separaciones, prohibiciones, órdenes, disposiciones. En el caso de La Mesa, el primer día que llegaron los paramilitares, el discurso del jefe paramilitar, alias '39', empezó a reconstruir relaciones y reconfigurar un nuevo orden social que el poder armado impuso y modeló.

Según Foucault (2008), hablar de poder y saber es hablar de política. La política invariablemente se reviste de relaciones de poder-saber y, de manera más explícita, de técnicas y dispositivos de control. Cada persona, cada mente, cada cuerpo es revestido por la política y es conformador de la política. La política se explica por las relaciones del ser aquí mismo y ser con los otros. El discurso paramilitar está asociado con una determinada representación social de la población de La Mesa. El discurso pone en acto, instituye, confirma relaciones de dominio y poder. El poder moviliza fuerzas, efectos, resultados, puntos de dominación en las relaciones cotidianas, moviliza subjetivaciones. El poder es una maquinaria de producir miedos y de dispositivos para mantenerlo vigente. 
El castigo -instaurado desde un discurso de exclusión- es una de sus técnicas, en donde el miedo es exaltado, reafirmado, y utilizado bajo las condiciones de situaciones ejemplares para apaciguar las mentes y los cuerpos de cada uno y de todos. Cuerpos moldeados y mentes modalizadas. El propósito del discurso de la vigilancia y la disciplina -que se despliega en La Mesa- es destruir las identidades fijadas, estabilizadas de antaño previamente por otras lógicas, otras racionalidades y otros discursos prácticos, y convertirlas en subjetividades dispersas. Una vez se instaura el discurso de división-exclusión (sospechosos-infractores), el miedo cruza toda comunicación directa o indirecta. Nadie sabe con quién habla realmente. El rumor, la sospecha, el señalamiento y la confesión, resultados del castigo y la disciplina, contribuyen a la erosión de la verdad colectiva. Las listas elaboradas de sospechosos, a partir del señalamiento de un informante anónimo, de un colaborador, de un 'soplón', impiden relaciones interactivas y comunicaciones sanas. Cualquier frase sacada de contexto convierte a una persona en peligrosa, en observable, en analizable.

La subjetividad va siendo moldeada por nuevas formas de disciplinamiento: en la medida en que se incrementan los interdiscursos del sometimiento, la subjetividad individual y colectiva van cambiando de forma, adquieren nuevas configuraciones que se extienden a la memoria corporal y a la conciencia.

Como punto de partida, hay que decir que Wodak (2000), Fairclough (2000), Jäger (2003) y Foucault (1980) coinciden en que el discurso es el eje constitutivo de toda interacción social, mediante el cual se ejerce un poder, dado que quien emite un discurso busca convencer y cambiar la mentalidad (valoraciones, puntos de vista, imaginarios) de los receptores, mediante la comunicación de creencias, actitudes, valores, entre otras formas, ya que a partir de los discursos se puede ejercer un control sobre la mente de un grupo determinado.

\section{El discurso paramilitar de alias " 39 "}

"Si el discurso consigue algún poder

es de nosotros de quién lo obtiene".

(M. FOUCAULT)

La llegada de los paramilitares del frente Mártires del Valle de Upar constituyó un acontecimiento comunicativo específico para algunos de los habitantes de La Mesa quienes, a las 5 de la madrugada del 23 de septiembre de 1999, se dirigían a las fincas a jornalear: "un grupo de hombres armados, vestidos con uniforme camuflado, los rostros cubiertos con pasamontañas, quienes luciendo sus fusiles Galil y R-15, recorrieron las calles del caserío. Los hombres armados no pronunciaron palabra. Nadie sabía que grupo armado había arribado al pueblo". 
Aunque no cruzaron palabras con los habitantes, los paramilitares empezaron a preparar el terreno para que la población incorporara su presencia como algo cotidiano en el territorio. Desde el primer momento, al cubrir con capuchas sus rostros y lucir su armamento, patentizaron las relaciones de poder, desiguales, que establecerían con los pobladores. Y también las condiciones del nuevo régimen que sería instaurado.

En La Mesa, los paramilitares hicieron su aparición, no como un actor armado más, sino como un contra-poder, opuesto a la presencia y acción de las Farc y el ELN, quienes durante casi quince años ejercieron dominio en la zona para la consecución de recursos económicos, a través del secuestro y la extorsión. Aunque similar en características externas, vestidos de camuflado, con pasamontañas, luciendo armas automáticas y 'posicionados' por encima de la población, los paramilitares llegaron para disputar espacios, mentes, cuerpos y discursos, presentándose como aliados de un Estado débil en presencia y resultados dentro de la ofensiva contra las guerrillas, pero necesitado de apoyo externo para equilibrar la asimetría en la guerra.

Ante la inoperancia de las autoridades de la Policía y el Ejército, las que no impedían los atentados contra sedes de las alcaldías locales, estaciones policiales, los asesinatos selectivos y la poca atención del gobierno central a la situación de orden público, algunos dirigentes políticos y ganaderos utilizaron ejércitos privados para defenderse de la extorsión guerrillera. Debido a esto, entre otras circunstancias, no se entendería de otra manera su presencia en el departamento y en la zona.

El 23 de septiembre de 1999 inaugura, para los habitantes de La Mesa, otra etapa de presencia armada en su territorio y tejido social, disponiendo de sus espacios, actividades, economías, remodelando su repertorio de imágenes y representaciones, recibiendo interpretaciones particulares, transformando las relaciones colectivas, los valores culturales, instalando de nuevo el miedo, la desconfianza, la incertidumbre. Es en este escenario social en donde se expresan las luchas por el poder, donde este extiende sus redes que alcanzan mentes y cuerpos (Faircloug, 2003).

Los paramilitares llegaron a la población para disputar el poder, para tomarlo y ejercerlo, a partir del desplazamiento del enemigo instalado allí, del adversario, que cuenta con colaboradores, a quienes hay que desterrar, y quienes no lo son, controlarlos, disciplinarlos, castigarlos. Ese 23 de septiembre dan la primera orden: "habrá una reunión a las 3 de la tarde en la cancha de fútbol, todo el pueblo debe asistir".

Para Jäger (2003), donde hay conocimiento hay poder y todo conocimiento está vinculado al poder. Al llegar a La Mesa, su comandante David Hernández Rojas, alias '39', dispone de un amplio conocimiento sobre la zona, anclado en dos experiencias de vida: la primera, como oficial del Ejército y excomandante de la unidad de Granaderos del Batallón La Popa, combatiendo allí a la guerrilla; la segunda, su permanencia durante 18 años en La Sierra, una de las veredas de La Mesa, azotada por los frentes 59 de las Farc y 6 de diciembre del ELN. Alias ‘39' le mandó a avisar al corregidor que habría una 
reunión en la cancha de fútbol y todo el pueblo debía asistir. No fue difícil dar con la identidad del líder comunal, lo conocía desde niño, el jefe paramilitar estudió de niño con sus hijos en la escuela La Montaña.

Sin embargo, en su aparición pública, escoltado por diez hombres, traía el rostro cubierto. En la cancha, como sitio de encuentros públicos y celebraciones, su poder armado lo despliega como un anónimo, alguien sin-rostro conocido, así se muestra ante la población. Nadie sabe quién es el que va hablar en la tarima: "el hombre, con sombrero de pava y el rostro cubierto por una pañoleta negra, subió a una pequeña tarima ubicada frente a los nueve líderes veredales, el corregidor y los habitantes que lo esperaban".

En la tarima, alias '39' genera un significado de dominio paralelo a la función propia del Estado. Viste el uniforme camuflado de los oficiales del Ejército, porta armas, despliega hombres armados en cada rincón de la población, es la manifestación de un ejercicio de poder y control basado en un conocimiento del que dispone: llegaron allí para ocupar el vacío que existe por la falta de presencia real del Estado, para imponer orden. Ese vacío lo ocupará de ahí en adelante el frente Mártires del Valle de Upar, como contrapeso a las actividades de otro poder-paraestatal: la guerrilla.9 Su emergencia en La Mesa responde a un acontecimiento: los propietarios y dirigentes gremiales del Cesar han creado sistemas de autodefensas con el fin de protegerse de las extorsiones y el secuestro y, más tarde que temprano, lo fusionan con los grupos paramilitares, el frente Mártires del Valle de Upar es una de sus expresiones. Los enfrentamientos en la región norte del Cesar y el área rural de Valledupar se producen en las zonas que están desprovistas de una sólida presencia de los organismos de seguridad del Estado y donde se concentran recursos económicos legales e ilegales.

Alias '39' y sus hombres están allí como una extensión (ilegal) 'representando' al Estado, con el que comparten la estrategia de contraofensiva antisubversiva para combatir a las guerrillas. El predominio territorial representa una forma de adquirir control sobre los habitantes de esa zona, en la que han hecho presencia las Farc y el ELN, por casi una década, y el objetivo es desterrarlos. El arribo del grupo armado a La Mesa, uno de los corredores estratégicos que une el norte con el occidente del Cesar, le descubrirá a sus habitantes que están en el medio de cálculos militares estatales, guerrilleros y paramilitares, en detrimento de su protección y seguridad locales.

El objetivo para Rodrigo Tovar Pupo, alias Jorge 40, comandante del Bloque Norte de las autodefensas, al que pertenece el frente Mártires del Valle de Upar, es reutilizar la población como escenario de luchas de poder, para que el régimen que va a instaurar funcione. La población es el campo de manipulación de relaciones de fuerza, bien 
para desarrollarlas en una dirección concreta, bien para bloquearlas, transformarlas o reconfigurarlas, dentro de esa relación saber-poder de la que dispone su enviado militar, alias ' 39 '.

La cancha de fútbol, como nuevo lugar de enunciación escogido por el jefe paramilitar, es el escenario donde ese contra-poder armado anuncia cambios y transformaciones en las interacciones de la comunidad, hace visibles a los destinatarios de su discurso, operando en las creencias individuales y sociales, como marcos reguladores de las interacciones y prácticas de los individuos, al interior de La Mesa.

\section{El discurso de alias ‘39' en la cancha de fútbol}

"Las autodefensas llegamos a La Mesa para limpiarla de guerrilla (Farc y ELN). El que quiera seguirnos no va a tener problemas, pero el que no se alineé debe atenerse a las consecuencias".

David Hernández Rojas, el comandante '39', confirma en la tarima lo que muchos de los pobladores sospechaban: "Llegaron los paramilitares". Precedidos de una fama de crueles y sanguinarios por lo que se conocía en la zona de sus incursiones en las poblaciones de municipios como Astrea, Bosconia y Codazzi, escenarios de masacres, despojo de tierras, desplazamiento forzado y asesinatos selectivos, especialmente de líderes campesinos, dirigentes comunales, y militantes de partidos de izquierda. El anuncio del advenimiento de otro poder armado presupone un conocimiento-del que el jefe paramilitar- dispone en esa realidad en la que se inserta: "llegamos a La Mesa para limpiarla de guerrilla”. Alias '39' es un sujeto entretejido con la realidad territorial en la que está. Pero él también tiene su propia representación de La Mesa, significándola: allí está la guerrilla y la población está 'sucia', hay que limpiarla de sus impurezas.

La Mesa adquiere una nueva significación, perdiendo su identidad previa de población trabajadora y pacífica: "la despensa agrícola de Valledupar". Es una superficie donde hay que ejercer poder y control, es un objeto diferente dentro de la lógica de guerra del paramilitarismo y por eso es urgente otorgarle un nuevo significado. A partir del señalamiento de alias '39', la identidad de la población queda enmarañada con otros significados que instaura desde la cancha de fútbol.

El jefe paramilitar empieza a prefigurar lo que se vendrá para la población con su presencia en La Mesa. Se dinamizará el despliegue de prácticas de dominación y control, en la red de relaciones en las que hace presencia de la guerrilla. Siguiendo a Foucault (1979), el discurso paramilitar autohabilita una intervención del grupo armado en las relaciones de los habitantes y sus distintos componentes: decisiones, medidas, enunciados, prácticas, que circulan en el tejido social. 
El lenguaje del jefe paramilitar está referido a una tarea higiénica de salud que debe realizar el poder armado que se instaura allí. Debe tener un carácter profiláctico, de saneamiento del cuerpo social -que para él- está enfermo, impuro, por la presencia guerrillera. Por eso es necesario intervenir las individualidades, que son la causa del desorden en el cuerpo social: "El que quiera seguirnos no va a tener problemas, el que no se alineé debe atenerse a las consecuencias”. Es decir, de ahí en adelante las acciones de todos serán objeto de vigilancia y análisis. Detrás de cada acción de cada uno de los pobladores hay una gran cantidad de conocimiento que debe ser acopiado para el propósito terapéutico anunciado.

Ese conocimiento que hay entre la población (Jäger, 2003) - quienes son guerrilleros y quienes no- ayudará a saber a los paramilitares qué está haciendo cada sujeto (los que los van a seguir) y el conocimiento 'oculto' en su acción de los que 'no se alineen'. Desde ese 23 de septiembre, las relaciones sociales, las prácticas de todo tipo por parte de los habitantes, estarán interpretadas a la luz de un significado asignado a las conversaciones cotidianas, las reuniones, las celebraciones comunitarias, los encuentros entre familiares, vecinos, amigos, compadres. El conocimiento en detalle de esta red de relaciones, el control de las prácticas sociales, de las actividades en el caserío y las veredas, en fincas, tiendas y salones comunales, produce una reelaboración de las identidades, a partir del señalamiento que alias '39' hace de la población: La Mesa es una comunidad problemática. El jefe paramilitar describe esa forma de ejercitar el poder como forma de gobernabilidad sobre las conductas obedientes y de las que no lo son (Foucault, 2008). Gobernabilidad-control que se extiende a la comunidad, en sus relaciones, sus comportamientos, sus mentes y sus cuerpos, instaurando un régimen de poder-saber, porque lo sucio debe sacarse de allí.

Para el jefe paramilitar, La Mesa es un cuerpo social enfermo que hay que curar y en esa tarea es fundamental la separación de sus habitantes: los que los sigan no tendrán problemas, aquellos que no se alineen deberán atenerse a las consecuencias, por su decisión. La presencia de la guerrilla en la zona -según '39'- posibilita que haya necesidad de desplegar una intervención externa -que el Estado no ha sido capaz de emprenderpara eliminar y erradicar a las Farc y el ELN del territorio: "Las autodefensas llegamos a La Mesa para limpiarla de guerrilla”.

El discurso paramilitar - como evento comunicativo de interacción (Fairclough \& Wodak, 200o) - dinamiza la emergencia de un poder que dispone, a partir de enunciados, un orden determinado, individual y social, para funcionar. Hernández Rojas siembra la duda sobre la claridad de las relaciones entre los habitantes de La Mesa. Si hay guerrilleros en el pueblo es porque esas relaciones colectivas no son transparentes, en ellas se oculta una verdad que es clandestina y que hay que develar. El nuevo orden poder-saber hace modificar la intensidad de las relaciones saber-verdad que las acompañan, para instaurar otra: poder-verdad. 
Esa nueva relación poder-verdad, que el jefe paramilitar insinúa desde la tarima, distribuye en las interacciones y prácticas sociales lo visible y lo oculto, lo dicho y lo no-dicho, al hacer emerger y, también desaparecer, a quien no se acople al nuevo orden social que se inaugura. De tal manera, que de ahí en adelante los sujetos no existen por fuera de esa nueva relación poder-verdad.

Con la llegada del frente Mártires del Valle de Upar, los sujetos, sus mentes, cuerpos, acciones, están asociados al resultado de una relación impuesta de mando-obediencia, órdenes-cumplimiento, control-acatamiento. El discurso de alias '39' agencia una interacción entre el sujeto y las prácticas de poder y control que se desplegarán en el territorio. El nuevo sujeto que crea ("el que quiera seguirnos no tendrá problemas") queda atado de alguna manera a la identidad creada y dominada por el poder armado, condicionando, de entrada su capacidad de actuar, de pensar, de relacionarse, de decidir, en ese cuerpo social que hay que limpiar.

Siguiendo a Fairclough (2003), el discurso dispone a los sujetos a establecerse en un régimen de verdad que circula por el territorio, por los lugares, las mentes y los cuerpos. El nuevo régimen de verdad, que se anuncia (en La Mesa hay guerrilla), desplaza lo que es actual, cotidianidad sin sujeciones, proliferación de otros discursos, solidaridades, cooperación, prácticas de intercambio de sentidos y representaciones, disfrute del tiempo libre, para sustituirlo por lo que va a devenir: prácticas de poder-verdad, sujetos disciplinados y 'otros-sujetos culpables', ubicados en la periferia, en los límites del orden establecido.

Esa transición, de un orden dado desde una lógica a un orden producido desde lógicas nuevas del paramilitarismo, implica la coexistencia entre matrices normativas de comportamiento y dominios de verdad-sujeción; transición de maneras de decir-hacer a maneras de conducirse-regularse el individuo, no solo consigo mismo, sino con los otros, en el lugar en donde conviven y se relacionan.

\section{"Enseguida bajó de la tarima y se dirigió hasta donde estaban los líderes comunitarios y los increpó: yo soy de aquí, soy de la región. Los conozco a to- dos ustedes y sé quién está con quién. Ahora las cosas van a ser de otro modo, venimos a quedarnos por tiempo indefinido".}

Foucault (2006) sostiene que el poder despliega una técnica de control. El propósito es instaurar un orden de disciplina, como constitutivo de poder-saber. Ese poder es productor y reproductor de saber: "Los conozco a todos ustedes". Alias '39' apela al conocimiento de la región y de los líderes, algunos de los cuales conoció cuando vivía en la vereda La Sierra, donde creció, estudió y visitaba los cultivo de café, yuca y plátano con los hijos de algunos de ellos. Sus palabras se remontan a un pasado, a un universo de conocimiento previo, a una experiencia de interacción con los oyentes, que trae al presente para refrescar la memoria de quienes son sus interlocutores. 
El caminar hacia donde estaban los líderes comunitarios, además de ser un gesto retador, patentiza las relaciones de poder desiguales que inaugura cuando los increpa, relaciones que de ahí en adelante serán de dominación y control armado, de las que nadie podrá escapar. Siguiendo a Foucault (2006), el poder está íntimamente ligado a un saber exclusivo, discriminante, que busca disciplinar el saber social: "yo sé quién es quién”. Ni los líderes de La Mesa se salvan de quedar atrapados en la maraña de las nuevas significaciones que el jefe armado despliega sobre la imagen y representación que tiene del caserío.

Al increparlos, Hernández Rojas deslegitima la autoridad de los líderes que están reunidos con toda la comunidad, levantando un manto de sospecha sobre el conocimiento que tienen de la situación. Ellos poseen un saber que él conoce: “yo sé quién está con quien”. Esa sospecha cubre todas sus acciones y decisiones. Si en La Mesa hay guerrilla es porque algunos, varios o todos los líderes la encubren o le colaboran tolerando sus acciones, o pertenecen a ella. A través de la estrategia de legitimación-deslegitimación, la realidad presentada por él no queda simplemente reflejada en sus palabras, sino que agencia una lucha que se empezará a desarrollar por la verdad o alrededor de ella, para controlar los discursos que circulen en las veredas El Mamón, Sabanitas, Las Estrellas, La Sierra y Cuba.

No hay ejercicio de poder posible -dice Foucault- sin afectar los discursos de verdad que funcionan en lo colectivo, no se puede ejercer poder sino a través de la producción de verdad, con miras a unos fines establecidos: "Ahora las cosas van a ser de otro modo, venimos a quedarnos por tiempo indefinido". El enfoque discursivo de '39' está centrado en lo que suceda, de ahí en adelante en las interacciones sociales concretas, al interior de la comunidad.

"Ahora las cosas van a ser de otro modo": el jefe del frente Mártires del Valle de Upar moviliza fuerzas, efectos resultados, puntos de dominación en las relaciones cotidianas. Los paramilitares son una maquinaria de producir miedos, incertidumbre, desconfianza, con el propósito de transformar identidades fijadas hasta ahora y modularlas, a partir de técnicas de disciplina, castigo y exclusión. Es reconfigurar un viejo orden contaminado -según la realidad que tiene '39' en su mente- y construir otro.

Para '39', la tarea encomendada por alias Jorge 40, no está sujeta a términos fijos: "venimos a quedarnos por tiempo indefinido". De acuerdo con su conocimiento de la zona y cumpliendo el objetivo general de las AUC - derrotar a la guerrilla en el norte del Cesar- la tarea de limpiar de guerrilleros a La Mesa será una tarea de largo aliento y por todos los medios posibles. La Mesa es un laboratorio de estrategia militar con miras a reducir y aniquilar las acciones e influencia de las Farc y el ELN, entre las comunidades campesinas, por el tiempo que sea necesario.

El escenario de esa confrontación, entre un poder instalado (la guerrilla) y un contrapoder que llega (los paramilitares), es la población, los 1200 habitantes que sufrirán 
profundos cambios, con miras a obtener unos fines políticos y económicos estratégicos. Con su discurso, alias ' 39 ' deja entrever que La Mesa es un espacio determinado, que debe ser acondicionado para operar transformaciones en su tejido social, espacio en el que se expresan las luchas de poder, que alcanzan las conductas, las relaciones, los cuerpos y las mentes que lo habitan (Fairclough, 2003).

\section{El discurso en el colegio: la cartilla de educación}

Una novedad acompaña la reunión de alias '39' con los líderes y habitantes de La Mesa, el domingo 24 de septiembre, en un salón del colegio “Virgen del Carmen”. Sus hombres llegan con una cartilla de educación cívica que ordena repartir entre todos los presentes: "La deben leer todos. Allí está lo que deben hacer para que no tengan problemas con nosotros. Todos los días deben salir a las 7 de la mañana a las fincas y parcelas a trabajar y regresar al pueblo a las 3 de la tarde, para que cumplan con trabajos comunitarios, de limpieza, arreglar los frentes de las casas que están dañados, desyerbar andenes, limpiar caminos. No quiero vagos aquí, el que roba es porque está desempleado, entonces vamos a trabajar todos”.

No es casual que alias ' 39 'ordenara que la nueva reunión se realice en el colegio y ordene entregar la cartilla de educación cívica, que "la deben leer todos". El proceso de reorganización social en La Mesa, no solo se propone liquidar a la guerrilla en las calles y caminos veredales, sino también en los espíritus, en las mentes y los cuerpos de los pobladores, disciplinando sus decisiones, a través de la reglamentación de los comportamientos.

“Allí está todo lo que deben hacer para que no tengan problemas con nosotros": dentro del orden del discurso, desplegado por el jefe armado, la cartilla, como texto escrito tiene la potencialidad de agenciar saberes, decisiones, representaciones, estabilizar conductas, inscribir en los cuerpos individuales un conjunto de prácticas, procedimientos, dictados desde el poder que empieza a copar todos los espacios del territorio habitado, para ajustar un orden social caótico y enfermo. Para él, la cartilla constituye el ejercicio de un poder que clasifica: "allí está todo lo que deben hacer", y al mismo tiempo lo que deben saber: "para que no tengan problemas con nosotros".

Más que regla de conductas que señalan límites al comportamiento, se trata de preceptos que modulan al sujeto en sus pensamientos y decisiones, movilizando un gobernarse así mismo. La cartilla - siguiendo a Foucault (Castro, 2011) - es una tecnología que promueve un cambio individual, mediante el autocontrol orientado a la codificación de las conductas y la definición estricta de lo que está permitido y prohibido dentro de La Mesa. Alias ' 39 ' busca crear nuevos sujetos, a través de un conjunto de disposiciones y aplicaciones, para poder administrar, controlar, orientar, inscribir sus mentes y cuerpos, y 
para disciplinar, corregir, curar lo que está enfermo en ellos. La cartilla es una herramienta de control que se inserta en el cuerpo social para ser interiorizada: "La deben leer todos".

Por eso es necesario, desde el interior del funcionamiento colectivo de la población, recodificar el cuerpo y la mente que se moviliza y actúa, a través de disposiciones, para su 'normalización', para reacomodar sus decisiones, sus conductas, sus comportamientos. Con la cartilla de educación cívica, ${ }^{10}$ los habitantes deben realizar un autoexamen personal, de cara a la vigilancia que será establecida para analizar si se está cumpliendo lo dispuesto en el texto escrito. El texto escrito es un campo de conocimiento en el que se deben inscribir todas las acciones y decisiones de la población. Un poder-de escritura como pieza esencial en los engranajes de la maquinaria disciplinar, constituida por el discurso, texto verbal del saber-verdad y la cartilla, texto escrito del saber-hacer.

El texto escrito apunta a producir un cambio individual, a través del examen personal sobre la adecuación de la conducta con el reglamento entregado, que articula saber y práctica, para movilizar un gobierno de-sí mismo, individual, que debe ser tarea de todos. Y nada mejor que promoviendo valores como el trabajo organizado, con horarios fijos, pensando en el "bienestar de todos", adecuando los espacios donde se vive y se realizan las actividades cotidianas y donde todos pueden participar: "Todos los días deben salir a las 7 de la mañana a las fincas y parcelas a trabajar yregresar al pueblo a las 3 de la tarde, para que cumplan contrabajos comunitarios, de limpieza, arreglar los frentes de las casas que están dañados, desyerbar andenes, limpiar caminos. No quiero vagos aquí, el que roba es porque está desempleado, entonces vamos a trabajar todos".

El vago, el que no hace nada, y el ladrón empiezan a ser prefigurados como sujetos que no deben estar en la población, son los otros-distintos. Su presencia desestabiliza el orden que alias '39' quiere en el territorio, el vago y el ladrón son insubordinados, hay que separarlos del resto o integrarlos al nuevo orden. "Entonces vamos a trabajar todos”.Es una orden, algo que se tiene que cumplir sí o sí. El trabajo -en la lógica argumentativa del jefe armado- 'educa al hombre, fortalece el alma, y forma el carácter del hombre', como aprendió de su padre en La Sierra y en los cuarteles. El trabajo, en

10. Durante su educación militar, el mayor David Hernández Rojas, alias ‘39’ realizó cursos de operaciones sicológicas, en las que estuvo en boga el conocido concepto maoísta, según el cual, "la guerrilla, apoyada por la población, se desenvuelve dentro de esta como pez en el agua”. Si la guerrilla está entre la población, se moviliza, planea acciones y cuenta con apoyo civil, hay que poner en práctica la estrategia de "quitar el agua al pez”. Desde esta concepción, los oficiales desplazados a zonas de orden público o 'zonas rojas', iniciaban jornadas cívico-militares, que incluían atención médica, alfabetización, capacitación técnica en actividades agrícolas de los campesinos, dentro de un proceso de normalización para devolver la población al Estado y corregir su rumbo. La jornada cívico militar finalizaba con la entrega de una cartilla a los habitantes para que avisaran a las autoridades de la presencia de guerrilleros y milicianos en la población, a cambio del pago de unas recompensas por su captura. O convertir a la población en informante de las autoridades, dentro de la Red de Cooperantes, muy extendidas en el país, durante los dos gobiernos del presidente Álvaro Uribe Vélez. 
el proyecto paramilitar, es esencial para el control de los hombres y mujeres porque pueden ser observados, vigilados en sus concentraciones más visibles, disponiéndolos en sus espacios más vitales.

El trabajo se convierte en una forma de ejercer un poder disciplinario, encargado de docilizar los cuerpos individuales, recortándolos de la masa, ubicándolos ordenadamente para ser observados en un espacio disponible a la vista de todos: regresar al pueblo a las 3 de la tarde para que cumplan con trabajos comunitarios, de limpieza, arreglar los frentes de las casas que están dañados, desyerbar andenes, limpiar caminos.

El discurso de alias '39', expresado en textos orales como escritos (la cartilla), teje una malla de efectos, desencadena un orden de conductas que pueden ser, además de observadas, controladas también. Con la cartilla de educación cívica se origina lo que Foucault (2008) denomina 'bíopoder', cuando el poder toma a su cargo la vida biológica de los sujetos y la convierte en objeto de regulación. El discurso instaura un 'poder disciplinario', disponiendo ordenadamente de los cuerpos y las mentes de todos y cada uno de los pobladores, de sus tiempos, a través del trabajo comunitario. Para Foucault, el 'biopoder' nose ocupa de cuerpos individuales, sino de poblaciones en su conjunto: vida biológica gobernada.

El discurso de lo que hay que hacer y no-hacer, se propaga, se inscribe en las conductas ("Vamos a trabajar a todos"), en las actividades, las comunicaciones, dentro de la población, para que la observación, como mecanismo disciplinario, no tenga fisuras, intersticios, que desestabilicen su ejecución. El régimen ver-saber se inscribe dentro de unas prácticas de control en los cuerpos, en los comportamientos, en la economía de las energías desplegadas. Todo el mundo está puesto y expuesto, todo el tiempo, a examen, a vigilancia, a escrutinio, a una regulación de sus energías y acciones.

A través del discurso, se despliega una técnica de control y su propósito es instaurar un régimen de disciplina, ligado a un saber prohibitivo, exclusivo, que ajusta los cuerpos: a partir de ese día quedó prohibido circular por las calles después de las seis de la tarde hasta las seis de la mañana y a las ocho de la noche las luces de las viviendas debían estar apagadas.

Sobre el fondo de una aparente inseguridad -para el jefe paramilitar- se construye una seguridad pública y privada, siempre al borde de sucumbir, y por ello demandante de más y más intervención. El nuevo orden social está expuesto a amenazas y oposiciones, mientras el enemigo (la guerrilla) siga allí, activo, clandestino, camuflado entre la población. Por eso es urgente someter todo su espacio vital a la vigilancia y regulación. Las funciones de legitimación, control, dominación, presentes en el discurso paramilitar, constituyen prácticas sociales discursivas (Van Dijk, 200o), por lo que el discurso cumple un papel fundamental en el proceso de reproducción de estas prácticas.

El discurso del jefe paramilitar opera en el campo de las representaciones sociales compartidas por los habitantes de La Mesa, en el conjunto de creencias en las que se 
organizan en términos correcto-incorrecto, prohibido-autorizado, y actúan conforme a esos principios, como marcos reguladores de las relaciones y las prácticas.

Les dijo que lo podían llamar comandante '39' y reiteró que “quien tenga vínculos con las Farc y el ELN debe confesarlo para no tener problemas y si no lo hacen, nosotros lo averiguaremos y sus familias sufrirían las consecuencias. Tengo una lista del tamaño de una hoja de periódico con nombres de sapos de la guerrilla. Así que deben hablar".

David Hernández Rojas se autonombra: ‘39'. Quiere que su identidad siga en el anonimato. Su rostro, cubierto por la pañoleta negra, será un enigma para los habitantes de La Mesa, potenciando la curiosidad por descubrir quién es.

“Quien tenga vínculos con las Farc y el ELN debe confesarlo para no tener problemas”. Hernández Rojas reitera la advertencia hecha en la cancha de fútbol, el día anterior: La Mesa será limpiada de guerrilleros, pero aquellos que tengan vínculos pueden confesarlo para que no tengan problemas. Y agrega un nuevo elemento, la confesión, que debe iniciar por un examen individual para corregir la conducta, de forma similar al orden religioso, como un camino para la redención.

Si la producción de verdad (discurso) está atravesada por relaciones de poder, la confesión es una muestra de ello. La confesión de la verdad (tener vínculos con las Farc y el ELN) está inscrita en el centro de los procedimientos de individualización, desplegados por la cartilla de educación cívica: 'No pertenecer a ningún grupo subversivo'. Aquí la confesión busca hacer pública ante el pueblo y los paramilitares una situación: la pertenencia a la guerrilla o la colaboración con ella. La limpieza de guerrilla, como objetivo militar en La Mesa, se inicia descubriendo quiénes son sus integrantes para erradicarlos, y esto se logra de manera persuasiva, para que confiesen, hagan pública su vinculación y las características de la misma.

Del discurso es posible inferir una dinámica de confesión-entrega-retribución, cuya dimensión de intercambio permite flexibilizar el tratamiento hacia quienes tienen vínculos. Si un sujeto confiesa la pertenencia a la guerrilla que, en el nuevo orden social es una obligación, recibirá un trato diferencial con relación a los que no lo hagan: "no tener problemas". La confesión alcanzaría un perdón, pero no inmediato, sería el resultado de la dinámica entrega-retribución.

"Y si no lo hacen, nosotros lo averiguaremos y sus familias sufrirían las consecuencias":el poder se expresa en un conjunto de disposiciones y aplicaciones que se pueden desplazar y transferir. La confesión hace emerger un conocimiento oculto, clandestino, no-visible. La vigilancia, como un tipo de control disciplinario, que se constituye a través de una red disimulada, difusa, anónima para la población, también puede hacer visible ese conocimiento (los vínculos con las Farc y el ELN), si es que se resiste y seguir siendo desconocido. Y habrá consecuencias por ello. Los integrantes de la guerrilla pagarán por esa pertenencia y sus familiares también, porque sabían y no lo confesaron. El 
propósito del ejercicio del poder es lograr autocontrol convirtiéndolo en el programa confesión-verdad-poder, a través de la puesta en marcha de mecanismos de disciplina, instaurados en el centro de las relaciones interpersonales.

“Tengo una lista del tamaño de una hoja de periódico con nombres de sa-
pos de la guerrilla. Así que deben hablar": cuando irrumpen en una nueva zona, los paramilitares disponen de un universo de conocimiento suficiente para detectar a aquellos que tenían lazos con las Farc y el ELN. En la disputa por los territorios, muchos guerrilleros, sobrepasados en capacidad logística y militar, se entregaron y decidieron integrar grupos paramilitares. Oriundos de las regiones conquistadas, conocían a los habitantes y aquellos que los apoyaron, antes de ser derrotados.

Estos nuevos paramilitares convertidos, 'desertores', 'sapos' para sus compañeros de militancia guerrillera, se convierten en el mejor instrumento para detectar y conocer quiénes, en las poblaciones, mantienen vínculos de lealtad con las organizaciones guerrilleras. Surge así el arrepentido, el guía, el observador, el redimido-colaborador, que interviene en el momento de las masacres paramilitares, señalando a quienes tienen nexos con la guerrilla. Generalmente cubren sus rostros con una capucha o una pañoleta, no hablan, sostienen en sus manos una lista con nombres y van señalando a quienes van a ser ejecutados.

Las masacres paramilitares se facilitaron, en muchas poblaciones, por la información (saber-verdad) entregada por individuos pertenecientes al círculo cercano de las víctimas: vecinos, amigos, compadres, conocidos, enemigos, deudores (Suárez, 2007). Para las víctimas, los delatores serán 'los sapos' que los condenan a una muerte dramática y segura. Para los paramilitares son 'arrepentidos', aquellos que hicieron un examen de su situación y decidieron cambiar de rumbo, pidiendo ser aceptados en el nuevo grupo armado que los derrotó: los redimidos.

Después de reunir a la población en la plaza del pueblo, los victimarios llaman a los 'sapos' para que reconozcan y señalen a los destinados a morir. La escena se repitió muchas veces en las poblaciones afectadas por la violencia paramilitar, desde 1995 hasta 2006, en treinta de los treinta y dos departamentos del país. Solo en Amazonas y Guainía no se presentó ninguna masacre durante ese período de violencia.

En La Mesa, alias '39' invierte el papel del 'sapo': son aquellos que le colaboran a la guerrilla. El sapo está del otro lado, no es todavía un aliado, es, sí, un potencial delator. Pero hasta no encontrarlos y obligarlos a desertar y confesar, serán sapos, colaboradores, guerrilleros de las Farc y el ELN. El jefe paramilitar va constituyendo la identidad individual y colectiva de la población. Esta incluye una colección de prácticas, acciones, experiencias personales y familiares, pertenecientes a sus enemigos. Y para demostrarlo ante los líderes y habitantes reunidos en el salón del colegio, anuncia que tiene una lista con nombres de 'sapos', que tienen relaciones con sus adversarios militares. Les hace saber que hay unos habitantes seleccionados que, con posterioridad, pagarán caro por su comportamiento de acomodo. 
Para el exmilitar, los 'sapos' desbordan el papel de los delatores. Los primeros están allí, se mezclan con los habitantes, de los que se han diferenciado en un momento dado. Aunque no los re-conoce, alias '39' asegura tener una lista de nombres, tan larga como la página de un periódico. Por eso es necesario que quienes tengan vínculos con la guerrilla se arrepientan y hablen.Solo así cambiaran de papel, de 'sapos' a delatores, de colaboradores a informantes.

Auxiliares del nuevo orden, para la difusión de la identidad de los enemigos. Poco importa que la pertenencia a la guerrilla haya sido voluntaria o una simple coexistencia suscitada por la presencia armada cotidiana en el territorio. Cualquier evento que se conozca sobre vínculos es suficiente para delatar a los sapos: una relación amorosa con un combatiente, el pago de vacuna extorsiva, la entrega de mercados, la asistencia a una reunión, dejarlos descansar en la finca. Cualquiera de esos eventos es motivo suficiente para tomar represalias.

Alias '39' convierte al enemigo en animal: "sapos de la guerrilla”. Significa reconfigurar la esencia del enemigo y sustituirla por la de un batracio, la proyección del enemigo sobre el animal es lo que impulsa a la configuración del exceso en el momento de actuar contra él, es un animal que se puede extirpar fácilmente. Los 'sapos' están dentro de la población y la población civil, como escenario de guerra, es considerada por el paramilitar fuente de respaldo económico, logístico, moral, político que activa una competencia entre los grupos armados, en razón de sus repercusiones sobre el balance de fuerzas y el desenlace final de la guerra que se librará en La Mesa.

La violencia que se ejercerá en el caserío está orientada a fracturar, prevenir e impedir afinidades entre la población civil y el enemigo (sapos -terror disuasivo- y guerrilleros -terror represivo-), acumular fuerzas y debilitar al adversario, y demostrar que es costoso seguir colaborándose entre ellos. Para alias '39', la población civil se encuentra profundamente dividida (realidad significada): por una parte, en ella se produce y circula información relevante para ambos actores armados; en segundo lugar, no es neutral, es un actor del conflicto, en su tejido social hay enemigos que se esconden, se camuflan, actúan desde allí, a la vista de todos y todos lo saben.

"Así que deben hablar": denunciar a los enemigos deroga sanciones, las reemplaza por beneficios materiales, recompensas en dinero, sacar la familia de la zona, integrar la estructura armada. Delatar a los 'sapos' es un medio para desequilibrar el balance asimétrico de fuerzas y, desde los paramilitares, demostrarle al enemigo que es impensable ganar la guerra allí.

\section{Exclusión-inclusión}

En la reunión en el colegio, ‘39' dividió a los habitantes en dos grupos: los sospechosos y los infractores. Los sospechosos son los que tienen vínculos con la guerrilla, los que le trabajan como informantes, guías y les venden alimentos. Los infractores son los 
borrachos, los ladrones, los infieles -sean hombres o mujeres-, los drogadictos, los mujeriegos. "Para todos hay castigo si no se alinean y cumplen con las disposiciones que están en el manual de educación y comportamiento que deben leer todos": en su discurso, el jefe paramilitar hace una dicotomía de la población, la disecciona en dos partes para asumir mayor control de sus quehaceres hasta el más mínimo detalle. Para Foucault (2006), el biopoder clasifica y sectoriza, separa y retícula a todos los individuos, a los cuerpos expuestos, alcanzados por el conocimiento. Es un discurso que fabrica sujetos y - a la vez- un colectivo como objetos de disciplina. La Mesa es un territorio de proscripción: ${ }^{11}$ "Los sospechosos son los que tienen vínculos con la guerrilla, los que le trabajan como informantes, guías y les venden alimentos".

El texto verbal hace emerger un poder apuntado hacia un individuo, que no podrá escapar, resistirse u oponerse, a toda una carga de control y represión que se desencadenará en el nuevo orden social que instala y en el que está inscrito.

Es en el tejido social donde el poder castigador se registra, se inscribe y se extiende a lo largo de la vida misma, especialmente en las acciones y en toda la población, por extensión. Es un poder-control que se hunde en las profundidades de la conciencia y los cuerpos de la población y, al mismo tiempo, penetra todas las relaciones sociales.

La guerrilla y sus colaboradores (los sospechosos) representan una amenaza, un riesgo para el nuevo orden social establecido y para la dinámica permitido-prohibido-hacer, contenida en la cartilla de educación cívica, repartida entre todos. Los infractores son los borrachos, los ladrones, los infieles -sean hombres o mujeres-, los drogadictos, los mujeriegos:el discurso moviliza una dinámica ritual -no solo por su carácter meramente lingüístico- en la que los sujetos se afirman y reafirman en sus papeles, sino también por el carácter intrínsecamente divisorio que implica la institución del poder, bajo la cual dichos sujetos se encuentran sometidos.

Los sujetos (sospechosos e infractores) se sitúan en la superficie de emergencia instaurada por el jefe paramilitar, visibles por su diferencia y heterogeneidad, en el lugar que ocupan determinado por el discurso paramilitar. Son 'modalizados' cuando son enunciados: "son los borrachos, los ladrones, los infieles -sean hombres o mujeres-, los drogadictos, los mujeriegos". La subjetividad creada inscribe en la mente y el cuerpo del habitante de La Mesa reglas, procedimientos, esquemas corporales y lógicos, que regirán para las variedades discursivas cotidianas que circulan (conversaciones, reuniones, encuentros, celebraciones) y en las articulaciones particulares de las prácticas sociales: familiares, de amistad, amorosas, laborales, de vecindad. 
Mientras los sospechosos serán tratados como enemigos, los infractores lo serán como transgresores. Son aquellos que infringen unas reglas, se sitúan por fuera del acuerdo establecido con la entrega de la cartilla de educación cívica, que regula los pensamientos, las acciones, las decisiones.

Ante la división sospechosos-infractores, alias '39' propone una salida: "no se busquen problemas, arreglen sus cuentas con nosotros, porque de aquí no nos vamos a ir hasta que esto no esté limpio completamente". Los que arreglen sus cuentas estarán por fuera de los dos grupos señalados, aunque sus acciones traspasan los 'límites normativos', podrán salvarse: “arreglen sus cuentas con nosotros”. De la única manera que es posible: confesando, haciendo públicas sus relaciones de colaboración. Es la estrategia de efectivizar el funcionamiento de las advertencias y amenazas que se ciernen sobre el todo social.

La sujeción de las mentes y los cuerpos, las acciones y decisiones, tomará forma de un reconocimiento al nuevo orden instaurado, a través de una renuncia de sí mismo para que todo funcione como se ha establecido. Re-conociendo su especificidad, con un estatus que lo individualiza (sospechoso-infractor-redimido-colaborador), cada sujeto debe escoger, con plena conciencia, entre lo que le conviene y lo que no.

El discurso del jefe paramilitar convoca a que se adopte un 'dominio de sí' como un gobierno subjetivo, gobierno que se debe extender a su familia, a su círculo de amigos, vecinos, de compañeros de labores. Lo normal no es que haya sospechosos ni infractores, sino redimidos - colaboradores.

"Cuídense, yo los conozco a todos, se quién es quién": alias '39' dinamiza en los que lo escuchan lo que Foucault (2008) denomina "inquietud de sí", transmitiendo una incertidumbre sobre el nuevo estatus, sospechosos e infractores, para que se controlen, se transformen, se rediman y colaboren, como única salida a una condición indigna de ser, según él. La 'inquietud de sí' en La Mesa es la base para un nuevo orden, es el suelo donde se asientan las nuevas relaciones, las interacciones de todos en el pueblo.

El discurso del jefe armado es moralizador: "no se busquen problemas, arreglen sus cuentas con nosotros", para que se transformen, se auto-disciplinen y reflexionen, con miras a una colaboración. Quien se gobierna así mismo - a partir de la inquietud de sí- puede llegar a ser libre, el control de su conducta constituye una manera de estar en La Mesa "sin problemas", solo así se puede vivir mejor en medio del ejercicio de un poder que domina y controla.

Alias '39' también activa una frontera: nosotros y ustedes. Es dentro de las interacciones sociales sobre las cuales opera esa diferenciación impuesta desde el discurso. Esa diferenciación impuesta conduce a la polarización como proceso de institucionalización para-estatal de las identidades. La polarización necesita de una división en el cuerpo social enfermo, suministrada por el mecanismo de activación de frontera, y no se puede 
materializar si esa división no tiene resonancia colectiva, es decir si la sociedad no está alineada en función de los actores armados en competencia.

Los que confiesen y colaboren -que se identificaran y serán identificados- se convierten en correas de transmisión y difusión,garantizando la expansión de la división social de La Mesa: sospechosos, infractores y redimidos-colaboradores.

La conversión sospechoso-redimido, enemigo-'amigo-colaborador' se inserta dentro de las lógicas de subordinación y exterminio que los paramilitares pusieron en marcha en las poblaciones que copaban, promoviendo la oposición interna contra la guerrilla, buscando cooptar apoyos y lealtades para garantizar el éxito de sus planes, con miras a la erradicación y/o desplazamiento de las Farc y el ELN.

"Porque de aquí no nos vamos a ir hasta que esto no esté limpio completamente": la inquietud de sí es una forma de iniciar la limpieza, la purificación de La Mesa. Esta debe ser una preocupación que empieza por cada individuo, para que sea un propósito de toda la comunidad. La inquietud de sí, que lleva a un 'dominio de sí', se convierte en una matriz rigurosa de control. No basta con que cada uno revise en qué grupo está y en el que quizás no esté: hay que hacerles patente que se les observa, se les analiza, se les controla. Es necesario intervenir las individualidades que son la causa del desorden en el cuerpo social, en el colectivo, a los sospechosos es necesario separarlos del resto, clasificarlos como los incurables, los 'no-deseados alli'. La tarea tiene fines terapéuticos, es necesario limpiar La Mesa de los agentes patógenos que la contaminan.

La vigilancia, el control, el castigo permean el tejido social cotidiano de La Mesa, hasta el punto de naturalizar la literalidad de la experiencia de victimización, que acompañará a los habitantes durante siete años de dominio paramilitar. El discurso de alias ' 39 ' incorpora la violencia como marco referencial para interpretar el mundo y la victimización (sospechosos-infractores) como forma pasiva de estar-en el mundo, padeciendo la potencia re-significadora de la incursión armada directa.

La piedra y los arcos de fútbol constituyen artefactos ${ }^{12}$ de una arqueología del sufrimiento, de la violencia, dinamizada en los discursos pronunciados por alias '39' el 23 y 24 de septiembre de 1999, frente a toda la población de La Mesa. Su discurso de legitimación-deslegitimación, exclusión-inclusión, sus regímenes de poder-saber, poder-verdad, verdad-saber, este último articulado en la cartilla de educación cívica, se desplazaron hacia la piedra y los arcos de fútbol como expresión material, visible, del nuevo orden social (poder-dominación-control-vigilancia-represión-muerte) impuesto durante siete años en esa región del Cesar. 


\section{Conclusiones}

El corregimiento de La Mesa, zona rural de Valledupar, sigue siendo un territorio marcado por los hechos que dejó el sometimiento paramilitar que estigmatizó a sus habitantes como 'sospechosos' (guerrilleros y colaboradores) e 'infractores' (delincuentes comunes) entre 1999 y el 2006. Padres, hijos, mujeres, vecinos, amigos, soportaron durante siete años estos señalamientos convirtiéndose en objetivo militar.

El paramilitarismo como, como actor discursivo, verbal y textual, inscribió su dinámica legitimación-deslegitimación en las estructuras del mundo subjetivo y colectiva de los pobladores, al desplegar en sus imaginarios una representación de su naturaleza social, que no correspondía con su realidad social.

Mediante el binomio exclusión-inclusión (redención), el paramilitarismo cultivó un sistema de normas con el que todos sabían que hacer y no-hacer, inscribiendo en la estructura de sus comunicaciones incertidumbre, desconfianza y prevención, afianzando u nuevo sistema de comportamientos, generado desde el poder-saber, saber-verdad, calificado como aceptable por los victimarios.

Ser calificado y clasificado de 'sospechoso' por los paramilitares desembocó en serias transformaciones en la representación de confianza exhibida e insertada en las maneras de relacionarse los habitantes y conocer a los otros, sus seres queridos, sus amigos, sus vecinos y compañeros de trabajo.

La violencia de los paramilitares del Bloque Norte provocó la desestructuración de proyectos de vida de sus víctimas, de los lazos sociales, de las relaciones con los lugares cotidianos a donde se dirigían todos los días a realizar actividades económicas, deportivas, lúdicas y de celebración, como la piedra y los arcos de fútbol, que terminaron convertidos en instrumentos de suplicio, que acabaron con la vida de decenas de personas, sin que se haya establecido una cifra aproximada. En tanto no se cuantifique ese número de víctimas, no se entenderá la magnitud de la tragedia.

Los imaginarios acerca de la cancha, la piedra y los arcos de fútbol, que circulan entre la población, están contenidos de imágenes de castigo, de sometimiento, de la inhumanidad de los victimarios, de su desinterés por el sufrimiento de sus víctimas, de dolor de quienes padecieron torturas y castigos, de la indignación y miedo de sus familiares, quienes presenciaron todo. Imágenes que hacen que recuerden con resignación lo que ocurrió allí durante siete años de presencia y dominio del frente 'Mártires del Valle de Upar de las autodefensas. 


\section{Bibliografía}

CASTRO, E. (2011). Diccionario Foucault. Temas, conceptos, autores. Buenos Aires: Siglo XXI Editores.

CINEP (ED.) (1995). Urabá. Informe de la Comisión Verificadora de los Actores Violentos en Urabá. El destino de la frontera - Urabá en los años 90 . Bogotá.

FAIRCLOUGH, N. y WODAK, R. (2000). "El análisis Crítico del Discurso”, en Van Dijk, T. (2000). (Compilador). El discurso como interacción social. Estudios del discurso: introducción multidisciplinaria. Barcelona: Editorial Gedisa S. A.

FAIRCLOUGH, N. (2003). El ACD como método para la investigación en ciencias sociales. En Métodos de análisis crítico del discurso. Barcelona: Gedisa.

FORCINI, A. (2012). Los umbrales del testimonio. Entre las narraciones de los sobrevivientes y las señas de la post dictadura. Madrid: Ediciones de Iberoamericana.

FOUCAULT, M. (1979).Microfisica del poder. Madrid: Las Ediciones de La Piqueta.

FOUCAULT, M. (1980). El orden del discurso. Madrid: Cuadernos marginales.

FOUCAULT, M. (1989). "El juego de Michel Foucault", en Saber y Verdad. Madrid: Ediciones de la Piqueta.

FOUCAULT, M. (2006). Seguridad, territorio y población. Clase del 11 de enero de 1978. México: Ediciones Fondo de Cultura Económica.

FOUCAULT, M. (2008). El gobierno de síy de los otros. Buenos Aires: Fondo de Cultura Económica.

JÄGER, S. (2003). Discurso y conocimiento: aspectos teóricos y metodológicos de la crítica del discurso y del análisis de dispositivos. En Métodos del Análisis Crítico del Discurso. Ruth Wodak, R. y Meyer, M. (Compiladores). Barcelona: Editorial Gedisa.

SUÁREZ, A. F. (2007). Identidades políticas y exterminio recíproco. Masacresy guerras en Urabá 1991-2001. Medellín: La Carreta Editores.

VAN DIJK, T. (200o). El discurso como interacción en la sociedad. En El discurso como interacción social. Barcelona: Gedisa.

VAN DIJK, T. (2009). Discurso y poder. Contribuciones a los Estudios Críticos del Discurso. Barcelona: Gedisa. 


\section{Anexos}



Fuente: Foto tomada por el autor.

\begin{tabular}{|l|l|}
\hline Fото 2 & El salón del Colegio Virgen del Carmen \\
\hline
\end{tabular}

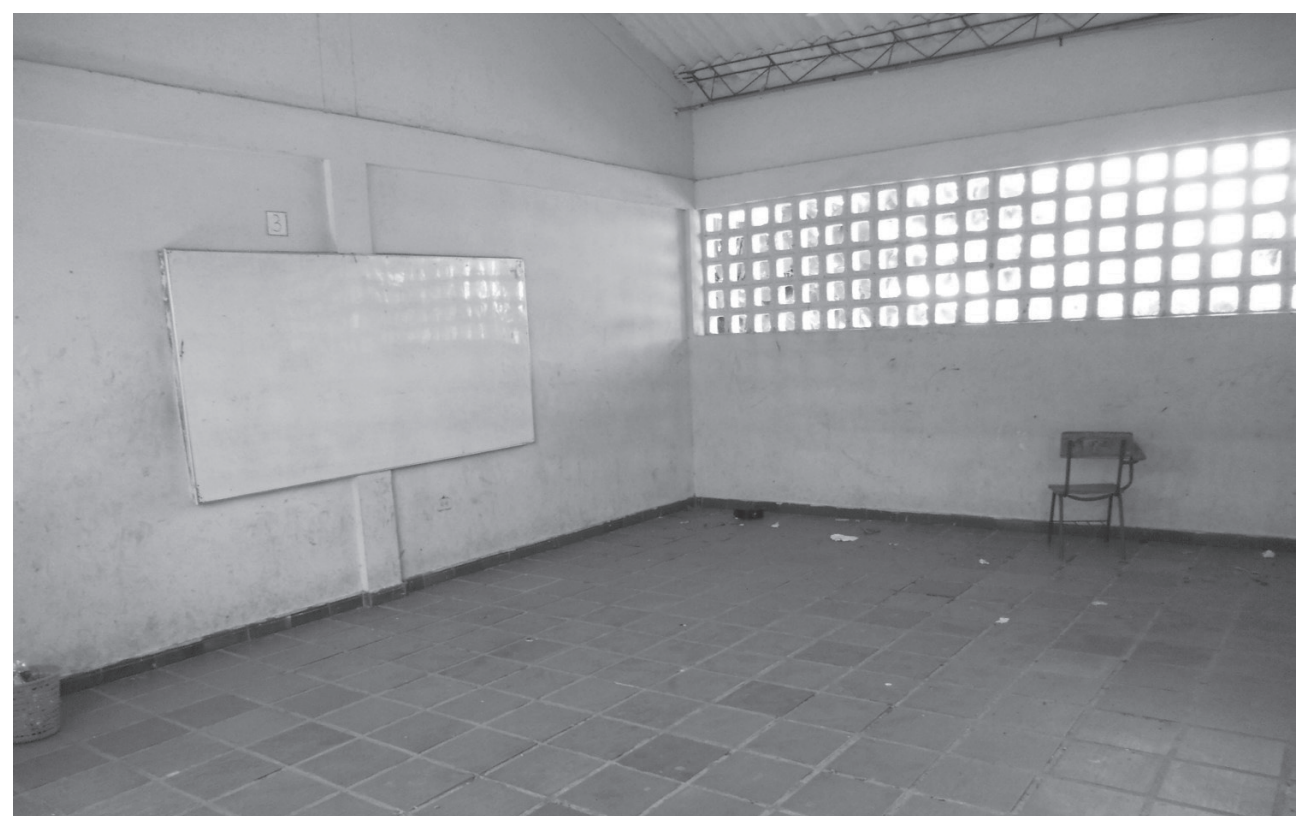




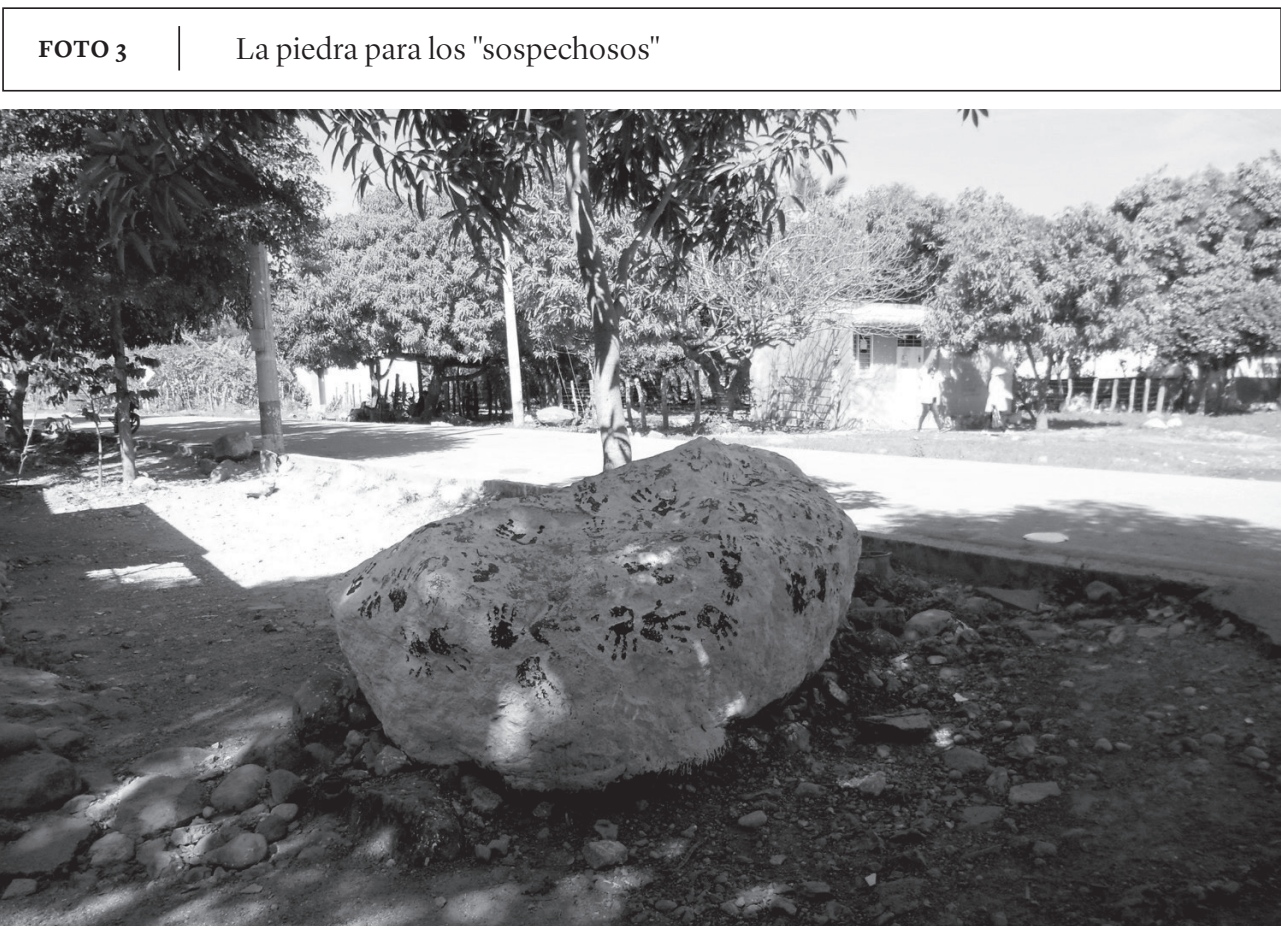

Fuente: Foto tomada por el autor.

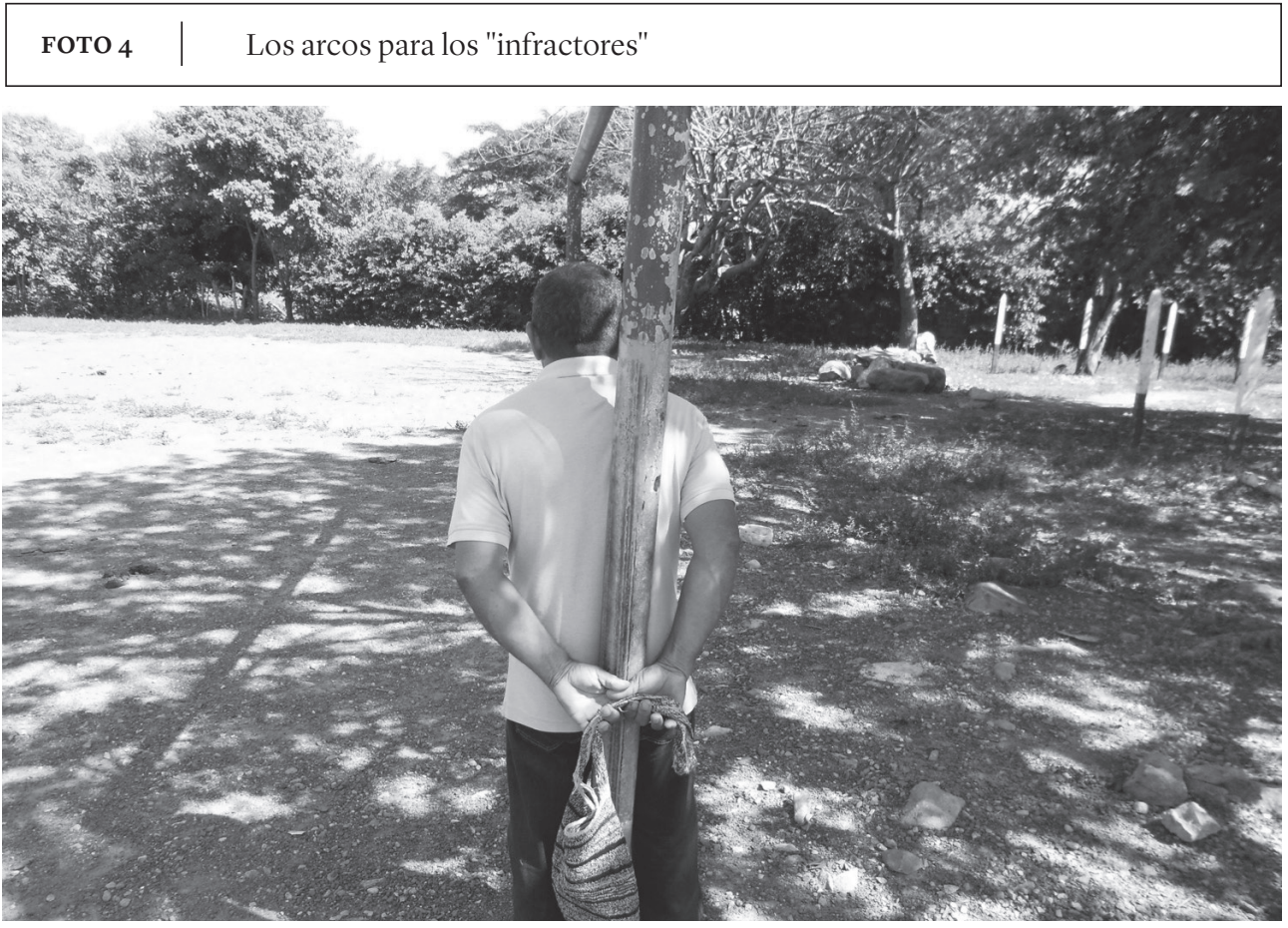




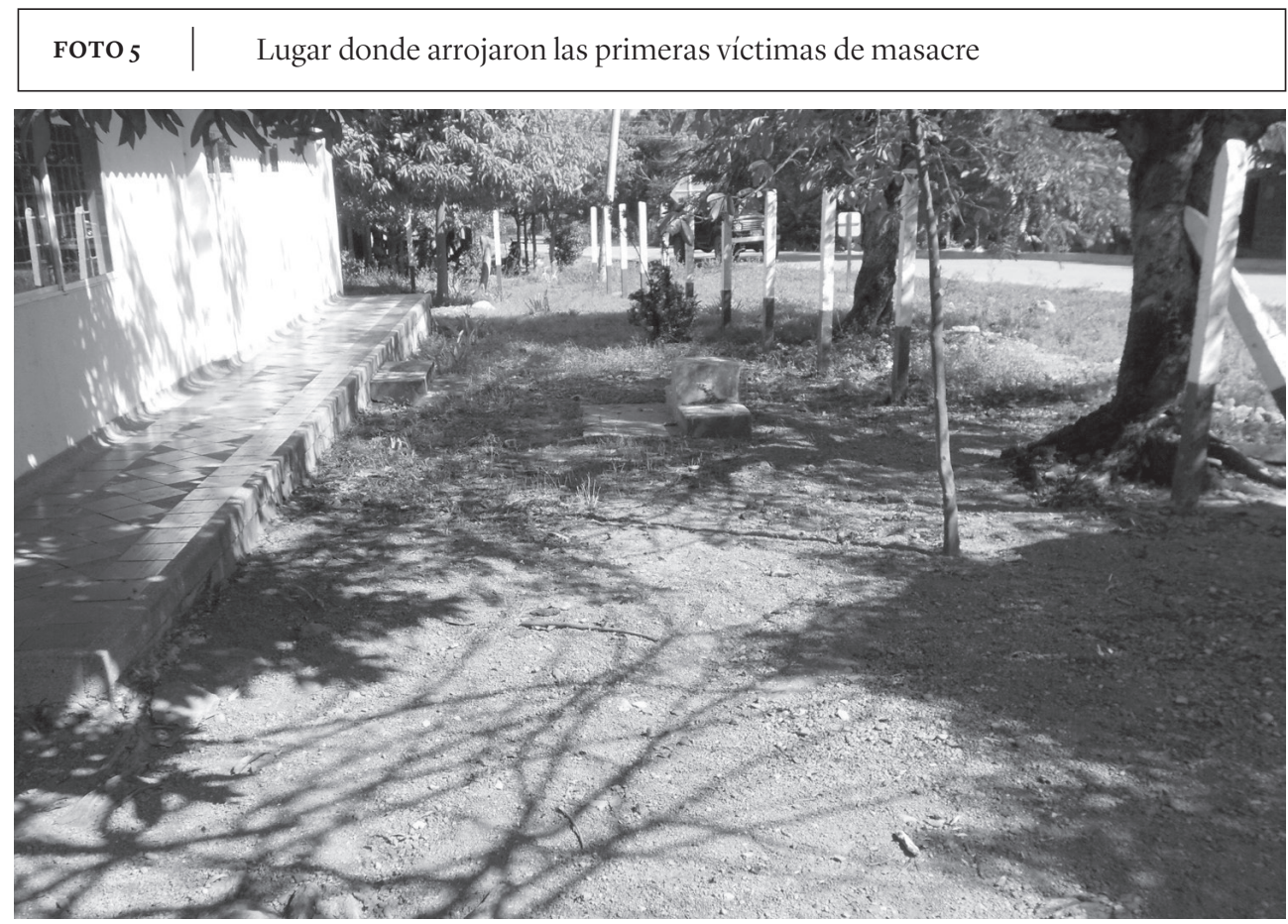

Fuente: Foto tomada por el autor.

\section{Leyenda de las fotos}

\section{Foto 1. El puente del Descanso Eterno}

En este puente caído, que está a dos kilómetros del batallón La Popa de Valledupar, los paramilitares instalaron el primero de tres retenes de vigilancia, a lo largo de la carretera que conduce a La Mesa. Los habitantes lo llamaron "El puente del Descanso Eterno", porque quienes llegaban allí y no tenían documentos de identificación, eran obligados a subir a motocicletas y días después aparecían muertos y con señales de tortura por los caminos veredales.

\section{Foto 2. El salón del Colegio Virgen del Carmen}

Colegio donde alias "39" dio su segundo discurso y dividió a los pobladores entre sospechosos e infractores. Además ordenó entregar una cartilla de educación a los líderes de la zona donde estaba lo que se debía hacer y lo que no. Hoy no se dan clases en él porque para los habitantes ese día se inició una etapa de desgracias para el pueblo.

\section{Foto 3. La piedra para los "sospechosos"}

Esta piedra, ubicada a la entrada de La Mesa, la convirtieron los paramilitares en un sitio de interrogatorios y torturas de aquellos que se acusaban de ser "sospechosos" de pertenecer a la guerrilla o ser sus colaborares, quiénes no portaban la ficha de color amarillo, que los identificaba como habitantes de la zona, o a quienes figuraban en "la lista de la muerte". A esta piedra los pobladores la llamaron "La piedra de los lamentos" y "La piedra de la ignominia", mientras que Salvatore Mancuso, en su visita a La Mesa, la llamó "la piedra de los milagros" porque aquellos que allísentaban "confesaban la verdad". Los sobrevivientes la pintaron de blanco y colocaron manos de colores sobre su superficie material, para recordar a los que estuvieron allí sentados y después fueron asesinados. Cada mano simboliza una víctima de los interrogatorios.

\section{Foto 4. Los arcos para los "infractores"}

Los arcos de la cancha de fútbol fueron convertidos en artefactos de castigo y disciplina. Pintados con los colores de la bandera nacional, allí permanecían amarrados semidesnudos los llamados "infractores" por los paramilitares. La imagen muestra cómo amarraban a los drogadictos, borrachos, desempleados y a los que armaban riñas y escándalos.

Foto 5. Lugar donde arrojaron las primeras víctimas de masacre

El sitio donde fueron arrojadas las 6 víctimas de la primera masacre en La Mesa. Sus familiares trataron de colocar allí una cruz y los paramilitares lo impidieron. 